\title{
Materials for a History of Hungarian Academic Orientalism: The Case of Gyula Germanus
}

\author{
Adam Mestyan \\ Cambridge, MA \\ mestyan@fas.harvard.edu
}

\begin{abstract}
This article provides materials for an institutional history of academic Hungarian Orientalism through the life of Gyula Germanus (1884-1979). Using hitherto unexploited archives, this text explores his education, integration into academia, and career up to 1939. I argue that Germanus was an assimilated Hungarian of Jewish origin with a strong loyalty to the state. His two conversions - to Calvinism in 1909 and to Islam in 1930 - also transformed him from a minor Turkologist into a popularly acclaimed Arabist. This study demonstrates that academic Orientalism as a national science was a contested vehicle of social mobility in the Hungarian transition from an imperial to a nation-state setting.
\end{abstract}

* I am grateful to Professors Sándor Fodor and Tamás Iványi for their advice on the initial phase of this research, which was inspired by a seminar hosted by Prof. Balázs Trencsényi at CEU. János Kubassek and Katalin Puskás of the Hungarian Geographical Museum, Vilmos Zsidi of the Corvinus University Archive, Edit Nagy of the Ráday Archive of the Dunamelléki District Hungarian Reformed Church and the staff of the Hungarian and the Egyptian National Archives provided guidance in their collections. The gratefully received suggestions of Balázs Ablonczy, Aziz al-Azmeh, Kata Bohus, Susannah Heschel, Imre Bangha, the participants of the "Transnational Islam in Interwar Europe" conference (University of Leiden, 12-14 December 2011), and the anonymous referees of Die Welt des Islams have been incorporated into the text. Ildikó Farkas generously shared her unpublished doctoral dissertation, Gábor Danyi provided research assistance, and Lina Mounzer, Sue Casson, and George Taylor edited the text. This project was completed during a fellowship at the "Europe in the Middle Eastthe Middle East in Europe" program of the Wissenschaftskolleg zu Berlin, 2011/12 (Forum Transregional Studien) when I was also affiliated with the Zentrum Moderner Orient, Berlin; I owe much to both institutions. Any mistakes remain mine alone. 


\section{Keywords}

Orientalism - Germanus - Goldziher - Vámbéry - Hungary - conversion - pilgrimage - PEN Club - Islam

A history of academic Hungarian Orientalism has yet to materialize. Such a history should address some crucial questions about the relation of scholarship and politics. How was Orientalism, especially Semitic Philology and Turkish Studies, institutionalized in Hungary? What explains the large number of Jewish Hungarian Orientalists? How did Hungarian Orientalists relate to the interests of the state? In what regard were they different from their Western European counterparts? How did historical problems (the mythic origins of Hungarians or the Ottoman occupation) inform their scholarship? What were the scholarly consequences of changing political regimes? ${ }^{1}$

Rather than seeking to present a general overview, I focus on the example of Gyula Germanus (1884-1979), who was also known as Julius and Abdul Karim ('Abd al-Karīm Jarmānūs). He has been the most widely known Orientalist in post-WWII Hungary. This article explains this popularity by tracing his life up to 1939. His unusual career opens a window on the institutional history of Hungarian Orientalism. Germanus' life provides an assimilation pattern of Hungarian Jews and, as a Muslim convert, he also played a small part in the modern history of Islam in Hungary. This study is based on hitherto unexplored archival sources and on a critical reading of Germanus' published work.

\section{The Making of a Secular (?) Orientalist}

Gyula Germanus ${ }^{2}$ was born in Budapest, on 6 November 1884, into a Hungarian Jewish family. ${ }^{3}$ There is no data so far on whether the Germanus family was

1 There is a growing literature on academic Orientalism in Hungarian. It includes digital projects at the Oriental Collection of the Library of the Hungarian Academy of Sciences; edited volumes by Mihály Dobrovits (Vámbéry-conferences) or by Ferenc Csirkés (Függőkert); important essays such as Éva Jeremiás' "Preface" in the Opera Omnia of Zsigmond Telegdi; and scattered recollections. Cf. the following footnotes.

2 Germanus is a pre-2oth-century Jewish family name. "Nyilatkozat" (Statement), dated 30 May 1940, in his personal dossier at 490 d, K636, Magyar Országos Levéltár (Hungarian National Archives; in the following MOL). Antall József, "Germanus Gyula családneve", in: Nagyvilág, Vol. XXV, 4 (1980), p. 603.

3 Biographies of Germanus include: Káldy-Nagy Gyula, "Julius Germanus”, in: Káldy-Nagy Gyula (ed.), The Muslim East: Studies in Honour of Julius Germanus (Budapest: Eötvös Lóránd 
involved in the Jewish social or religious life in Budapest, but some elements of Judaism were present in the family as befitted the blurred identities of Hungarian Jewry after the 1867 emancipation law. ${ }^{4}$ The previous generation of Hungarian Jewish Orientalists, such as Ármin Vámbéry or Ignác Goldziher, were exposed to a Hebrew religious education in the countryside. Germanus did not receive education in Hebrew but he was exposed in Budapest to state education in primary and secondary schools in the Hungarian language. ${ }^{5}$

In the first decade of the 2oth century, (Austro-)Hungarian Orientalism was in its final stage of belated institutionalization. ${ }^{6}$ In Budapest, four higher educational institutions served interested students. The Royal University of Sciences (originally a Catholic establishment, 1635/1777) hosted Chairs in Semitic Languages and Turkology, while the Hungarian Royal Academy of Oriental Trade (Oriental Academy, 1883/1899) trained experts in trade and foreign relations with "Oriental" countries, including teaching Turkish and Arabic. ${ }^{7}$ The Jewish Theological Seminary (Jewish Seminary, 1877) and the Theological

Tudományegyetem, 1974), pp. 7-10; obituaries in the Hungarian press during 1979 and 1980; Antall József, “Germanus Gyula (1884-1979)”, in: Antall József (ed.), Germanus Gyula, Gondolatok Gül Baba sírjánál (Budapest: Gondolat, 1984), pp. 303-324; Germanus' A félhold fakó fényében, published first in 1957, is considered here as a semi-autobiography, in a new edition: Germanus Gyula, “A félhold fakó fényében”, in: Germanus Gyula, Kelet varázsa (Budapest: Magvető Könyvkiadó, 1979), pp. 11-210. Cf. Dávid Géza, "A Bibliography of Julius Germanus", in: Káldy-Nagy (ed.), The Muslim East, pp. 253-264. Gyula and his brother Ferenc(z)'s German/Hungarian childhood letters are in Boxes 18 and 36, Heritage of Gyula Germanus (personal papers of Germanus) in Magyar Földrajzi Múzeum, Érd (Hungarian Geographical Museum, Érd; in the following MFM). On the language of Hungarian Jews, cf. István Ormos, "Goldziher's Mother Tongue: A Contribution to the Study of the Language Situation in Hungary in the Nineteenth Century", in: Éva Apor and István Ormos (eds.), Goldziher Memorial Conference (Budapest: MTAK, 2005), pp. 203-243.

4 Gyurgyák János, A Zsidókérdés Magyarországon (Budapest: Osiris Kiadó, 2001), pp. 61-87. Vera Ránki, The Politics of Inclusion and Exclusion: Jews and Nationalism in Hungary (New York: Holmes and Meier, 1999), pp. 72-77.

5 He studied at the "elemi népiskola" in Kazinczy Street and between 1894 and 1902, at the secondary school of the seventh district (VII. kerületi [józsefvárosi] községi főreáliskola). Certificates, Box 36, MFM. There is no evidence that he also studied at primary school in Lőcse (Levica, modern Slovakia), as stated in Lendvai Timár Edit (ed.), Germanus Gyula A tudós és az ember (Érd: Magyar Földrajzi Múzeum, 2009), p. 13.

6 Suzanne L. Marchand, German Orientalism in the Age of Empire: Religion, Race, and Scholarship (Washington, DC: German Historical Institute, 2009), pp. 74-78.

7 "Magyar Királyi Keleti Kereskedelmi Akadémia". Cf. Mihalik István, Szögi László and Zsidi Vilmos, "A Collegium Oeconomicumtól a Budapesti Corvinus Egyetemig", in: Szögi László and Zsidi Vilmos (eds.), A budapesti Corvinus Egyetem Levéltára, 1891-2001: Repertórium (Budapest: Corvinus Egyetem, 2004), pp. 5-25. 
Academy of the Reformed (Calvinist) Church (1855) also taught Hebrew and Arabic. At the Royal University, after Péter Hatala (1832-1918), the ex-Catholic priest Professor of Semitic Languages retired, Goldziher was appointed as an ordinary university professor in $1905 .{ }^{8}$ There was some interaction between the two state, "secular" institutions (the Royal University and Oriental Academy) and the two non-state, "religious" ones (the Jewish Seminary and Calvinist Academy).

The young Germanus, fascinated by images of a Muslim city in a tabloid, probably began studying (Ottoman) Turkish alone. After leaving secondary school, he travelled to Bosnia-Herzegovina (which had been under AustroHungarian military occupation since 1878). ${ }^{9}$ From 1903 he read history at the university, with a particular focus on Ottoman history. Despite his later recollection of Vámbéry and Goldziher as his professors, ${ }^{10}$ compared to his classes in history and Turkish, the time he spent studying under these two scholars during his four years at university was relatively short. ${ }^{11}$

Austro-Hungarian Orientalists sent students abroad in order to familiarize them with foreign languages and people. Ignác Kúnos (professor of Turkish philology at the Royal University and Director of the Oriental Academy) took his pupils to Istanbul annually, for an excursion or a short course of study. According to Germanus, once he joined Kúnos' group, subsequently remaining in Istanbul to study at the Faculty of Law of Dar ül-Fünun (Dār al-Funūn). ${ }^{2}$ He spent further time in Istanbul, ${ }^{13}$ after which he travelled to Anatolia in the summer of $1906,{ }^{14}$ possibly funded by payment from Vámbéry for translating some Turkish texts into German. ${ }^{15}$ Although the reader of his recollections gets the impression that he spent years in Istanbul, ${ }^{16}$ it might have been far

8 Goldziher Ignác, Napló (Budapest: Magvető, 1984), p. 285.

9 Germanus, "A félhold fakó fényében", p. 18.

10 Germanus, "A félhold fakó fényében", pp. 18ff. Lory Alder and Richard Dalby, The Dervish of Windsor Castle: The Life of Arminus Vámbéry (London: Bachman-Turner, 1979), pp. $492 \mathrm{ff}$.

11 "Index", Box 36, MFM.

12 Germanus, "A félhold fakó fényében", p. 23.

13 Letter dated 25 June 1910, from Germanus to Director of the Theological Academy of the Reformed Church, in Box 1, A/13, A Dunamelléki Református Egyházkerület Ráday Levéltára (the Raday Archive of the Dunamelleki District of the Hungarian Reformed Church, in the following RL).

14 His Ottoman mürur tezkeresi (internal passport, murūr tadhkarasī) is dated rümī 29 Haziran 1322 which makes 12 July 1906. Box 36, MFM.

15 Alder and Dalby, The Dervish of Windsor Castle, p. 492.

16 Describing his leaving Istanbul, Germanus writes: "My friends accompanied me to the 
less. ${ }^{17}$ His other experience abroad was at the University of Vienna. ${ }^{18}$ There he attended lectures in history and literature, and a class in Arabic for approximately three months. ${ }^{19}$

\section{Preparation for a Professional Career}

Germanus' doctorate in Budapest was granted with a summa cum laude in Turkish language and literature, Arabic language and literature, and ancient history in $1907 .{ }^{20} \mathrm{He}$ acquired his title in Arabic after completing only three classes with Goldziher and one in Vienna. ${ }^{21}$ As to his early publications,

station. They were perhaps more than friends, they were my brothers. The years and the shared dreams melted our hearts together." Germanus, "A félhold fakó fényében", p. 80.

Prof. Aladár Ballagi on 27 (29?) May 1906 signed his index and Germanus travelled to Anatolia on 12 July 1906. Box 36, MFM. Yet, he mentions in his memoirs the "pleasant August weather" in Istanbul, before his trip to Anatolia, Germanus, "A félhold fakó fényében", p. 45., and also that he participated in many gatherings during the "Ramazan of that year", again, before the trip, Germanus, "A félhold fakó fényében", 37, that would be October/November of 1905 (Ramaḍān of hijrī 1323). In a later letter, Germanus claimed that he spent the whole academic year 1905/1906 in Istanbul (Letter dated 25 June 1910, from Germanus to the Director of the Theological Academy of the Reformed Church, Box 1, A/13, RL). This claim suggests that he was in Istanbul from at least October 1905 to August 1906 but, based on his university index, he could not have been there so long. No evidence has yet emerged of his legendary imprisonment in Istanbul. The materials of the "Konstantinápolyi Császári és Királyi Főtörvényszék", do not contain his name. Praesidial Einzeichnungs-Protocoll für das Jahr 1903, 1904, 1905, 1906, K436, MOL. It is possible that, in Vienna, there is some documentation as yet unfound. Germanus' own earliest recollection is from 1917: "fifteen years ago, I distributed the secret pamphlets of the Young Turks in Anatolia." Germanus Gyula, “Kulturális problémák Törökországban”, in: Magyar Figyelo", Vol. 10 (1917), pp. 251-261, here p. 261.

18 Officially from 15 October 1906. "Matrikelschein”, University of Vienna, Box 36, MFM.

19 "Frequentations Zeugnis", University of Vienna, dated 15 January 1907, Box 36, MFM.

20 Germanus states that it was summa cum laude in a letter dated 25 June 1910, from Germanus to the Director of the Theological Academy, Box 1, A/13, RL. The diploma was dated 31 May 1907. Cf. his personal dossier, opened on 6 April 1912, 6/b 35, A budapesti királyi magyar Tudományegyetem Közgazdaságtudományi Kar Dékáni Hivatala iratai (in the following $\mathrm{KKDH}$ ), Budapesti Corvinus Egyetem Levéltára (in the following BCEL). (Documents of the Dean's Office at the Economics Faculty at the Hungarian Royal University of Sciences in Budapest in the Archive of the Corvinus University in Budapest). Goldziher sometimes granted students a doctorate without much knowledge. Goldziher, Napló, p. 356 . 
Germanus later claimed a contribution to Kúnos' Ottoman Turkish Grammar. ${ }^{22}$ He also claimed to have produced "a huge essay" in German, entitled "Geschichte der osmanischen Dichtkunst", ${ }^{23}$ of which there is no trace; rather, we find his long review of Gibb's A History of Ottoman Poetry. ${ }^{24}$ His Hungarian essay “Evliya Çelebi on 17 th-Century Turkish Guilds" was published in $1907 \cdot{ }^{25}$

Germanus became the protégé of Vámbéry, as he said, his "last student" and "grateful son". ${ }^{26}$ Probably due to Vámbéry's support, his career was advanced by a grant, covering a one-year research stay in England during $1908 .{ }^{27}$ Germanus studied the "Oriental historical manuscripts at the British Museum, the Bodleian Library, etc.", ${ }^{28}$ without an explicit research agenda. The young doctor wished to become a journalist in England, ${ }^{29}$ but Vámbéry suggested that he should apply for the professorship that he was vacating in $1909 .{ }^{30}$ There is no indication that Germanus ever put in an application, though he returned during the same spring to Budapest. ${ }^{31}$

22 Kúnos Ignác, Oszmán-török nyelvkönyv (Budapest, 1905).

23 Germanus, "A félhold fakó fényében", p. 81.

24 Julius Germanus, no title, dated "Wien, 1906", in: Keleti Szemle, n. 7 (1906), pp. 347-368. He wrote other reviews between 1907-1909 for Keleti Szemle.

25 It also appeared in Keleti Szemle (edited by Ignác Kúnos and Bernát Munkácsi) in 1907 and 1908 in two parts: Germanus Gyula, "Evlija Cselebi a XVII. századbeli törökországi czéhekről”, in: Keleti Szemle, n. 8 (1907), pp. 306-323 and n. 9 (1908), pp. 95-126. József Antall perhaps exaggerates when he attributes the birth of the Hungarian school of Turkology to the stimulating effects of this essay. "Evlija Cselebi a XVIII. századi törökországi céhekről”, in: Gondolatok Gül Baba sírjánál, p. 327, note 17.

26 Alder and Dalby, The Dervish of Windsor Castle, p. 492.

27 Letter dated 14 December 1907, Box 36, MFM. Antall, "Germanus Gyula (1884-1979)", pp. $306 f$.

28 Letter dated 25 June 1910, from Germanus to the Director of the Theological Academy of the Reformed Church, Box 1, A/13, RL. I have not found any trace of Germanus at any Oxford college so far.

29 Letter dated 7 October 1908, from Vámbéry to Germanus, Box 36, MFM.

30 Letter dated 19 February 1909, from Vámbéry to Germanus, Box 36, MFM.

31 Germanus arrived in Budapest in June 1909. Letter dated 25 June 1910, from Germanus to the Director of the Theological Academy of the Reformed Church, Box 1, A/13, RL. Cf. 6/b 35 , KKDH, BCEL. Thus his later narrative of collecting "the honey of knowledge for years" in England (Germanus, "A félhold fakó fényében", p. 81; repeated in Antall, "Germanus Gyula [1884-1979]", p. 307) is exaggerated, as he spent 18 months (January 1908-June 1909) there. 


\section{The First Conversion and Academic Integration}

Germanus converted to the Calvinist faith and joined the Hungarian Reformed Church on 11 October 1909. ${ }^{32}$ Just as no proof survives of his spiritual allegiance to Judaism, there is no sign of any real commitment to Calvinism, apart from some letters addressed to authorities in the 1930s. Perhaps it was a logical step for a young Hungarian of Jewish origins towards Hungarian assimilation, or a necessary one to secure a state position, as many other cases, including that of Vámbéry himself, may illustrate. ${ }^{33}$ Instead of receiving a university professorship, Germanus offered to teach Ottoman Turkish and Arabic at the Oriental Academy in 1909, and the following year at the Theological Academy of the Reformed Church.

Germanus connected religion and his career. In his job application letter to the Theological Academy he mentions his gratitude to the Director (István Bilkei Papp) and to a certain Reverend Dr. Szabó, through whose help he has been "received, or rather, returned (!) into the bosom of the Reformed Church in Budapest". He asked the Academy to let him teach three classes of Arabic for beginners and a "cultural historical" class entitled "The Appearance of Mohamed". ${ }^{34}$ Although the professors pared down his request, ${ }^{35}$ he was allowed to teach Arabic from 1911, but without any compensation. ${ }^{36}$

From the autumn of 1909, he also taught language at the Oriental Academy, under the directorship of Kúnos, again without compensation. ${ }^{37}$ There is no

32 Letter dated 25 June 1910, from Germanus to the Director of the Theological Academy of the Reformed Church, Box 1, A/13, RL. For the exact date cf. his "Nyilatkozat" (Statement), dated 30 May 1940, 490 d, K636, MOL.

Previous researchers thought that Vámbéry joined Calvinist circles "casually", cf. Alder and Dalby, The Dervish of Windsor Castle, pp. 249f. However, recent research established that Vámbéry officially turned Calvinist in 1864. Welker Árpád, "Vegyes házasságok és vallásváltások a Kálvin téri gyülekezetben a 19. században”, in: Kósa László(ed.), Reformátusok Budapesten I-II. Tanulmányok a magyar fôváros reformátusságáról (Budapest: Argumentum - ELTE BTK Művelődéstörténeti Tanszék, 2006), pp. 147-171, here: p. 169.

"Mohamed fellépése". Letter dated 25 June 1910, from Germanus to the Director of the Theological Academy of the Reformed Church, Box 1, A/13, RL.

35 "Jegyzőkönyv", note dated 11 September 1910, in Tanári ülések jegyzőkönyvei, 1902-1914, RL.

36 Letter from Kúnos to the Minister, dated 26 January 1912, in Keleti Akadémia Igazgatói Hivatal iratai, Iktatókönyv (Registry of Documents of the Director's Office of the Oriental Academy; in the following KAIH I), BCEL. Cf. also "Jegyzőkönyv a dunamelléki egyházkerület theológiai választmányának üléséről", dated 19 June 1912, Box 2, A/13, RL.

A table dated 6 May 1917 indicates that Germanus started working at the Oriental Academy from September 1909, Box 1916/17, Keleti Akadémia Igazgatói Hivatal iratai 
evidence of any academic income from spring 1909 until April 1911, when he began to receive a modest salary from the Oriental Academy. ${ }^{38}$ Perhaps this explains why his main activity during this period was contributing to English dictionaries rather than scholarly publications. ${ }^{39}$ Finally, Germanus was appointed a language teacher at the Oriental Academy on 26 March 1912. ${ }^{40}$ Following his conversion, and having worked without compensation for around two years, he was thus accepted into the state educational infrastructure.

\section{Orientalism and the Hungarian Imperial Idea}

Why did four higher educational institutions offer "Oriental" languages in preWWI Budapest? Judaic and Christian higher education included Hebrew and Arabic (and often Turkish) for the purposes of exegesis and Christian mission. The study of Turkish was important to solve four historical puzzles: the HunAvar-Hungarian relations, the original homeland of Hungarian tribes, the origin of the Hungarian language, and the classification of the Cuman (Kun) language. ${ }^{41}$ The answers were essential for articulating national identity. Among the "Oriental Hungarian" theories we find the influential Turanism, preaching a Turanian people in Asia whose supposed leaders in Europe were the

(Documents of the Director's Office of the Oriental Academy; in the following KAIH), BCEL. Cf. also Draft dated 7 December 1909, from Kúnos to Minister of Education, KAIH I, BCEL.

38 Letter dated 16 January 1912, from Kúnos to Minister, in KAIH I, BCEL. Note dated 30 April 1911, in KAIH I, BCEL.

39 Dávid, “A Bibliography”, pp. 254f.; art. 12-13, 15-16-17, 21, etc. He also published two essays concerning Ottoman history in 1910.

40 Germanus had already requested an appointment during autumn 1911, according to a note by the Secretary of State (Államtitkár) to the Board of the Oriental Academy (A magy. kir. Keleti Kereskedelmi Akadémia felügyelő bizottságának), dated 5 December 1911, KAIH I, BCEL. Germanus took the oath as a state servant on 5 April 1912. Note in KAIH I, BCEL, the text is in $6 / \mathrm{b} 35, \mathrm{KKDH}, \mathrm{BCEL}$. His appointment was signed by the Minister of Education on 26 March 1912, 6/b 35, KKDH, BCEL. Thus his claim to have been "invited" to teach at the Oriental Academy is misleading. Germanus, "A félhold fakó fényében”, p. 81. Ligeti Lajos, "Az Akadémia könyvtára és az orientalisztika”, Magyar Könyvszemle, 1 (1977), pp. 3-13. There has been also significant research on the Ottoman conquest of Hungary, including the quest to regain the precious medieval library of King Matthias. Arbanász Ildikó and Csorba György, "Magyar kutatók az isztambuli levél- és könyvtárakban a második világháború előtt", in: Dobrovits Mihály (ed.), A kísérlet folytatódik - Vámbéry tanulmányok II (Dunaszerdahely: Lilium Aurum, 2005), pp. 7-46. 
Hungarians. ${ }^{42}$ Its institutional expression was the Turan Society, modelled on the learned Asiatic Societies. ${ }^{43}$ On the other hand, the state educational context was politically informed by the 1908 Austro-Hungarian annexation of BosniaHerzegovina. ${ }^{44}$ To ease the administration of the new Muslim province, the government invited a group of Muslim students from Bosnia, with an Istanbuleducated imam, Abdul Latif (1886-1946), to Budapest. ${ }^{45}$ The intersection of identity debates with expansionism produced a particular "Hungarian imperial idea". ${ }^{46}$ This social and political buzz about "the Orient" explains the need for teaching Oriental languages.

Germanus offered his services to the Turan Society in October 1912 (by which time he was probably already a member) $\cdot{ }^{47} \mathrm{He}$ was interested in its agenda, which possibly helped him to make useful contacts with politicians and senior scholars, but he does not appear to have participated in its post-1914 activities (even if he remained its "honorary secretary"). ${ }^{48}$ In addition, in 1913, Germanus was among those who greeted the "Master", son of the founder of the Bahá'i

42 Farkas Ildikó, "Turánizmus" (unpublished PhD dissertation, Budapest, 2001); Ablonczy Balázs, “'Lándzsahegy,' néprokonság, small talk - Turanizmus és keleti gondolat a két világháború közötti magyar külpolitikai gondolkodásban”, in: Magyar külpolitikai gondolkodás a 20. században - A VI. Hungarológiai Kongresszus (Debrecen, 2006. augusztus 22-26.) szimpóziumának anyaga, szerk. Pritz Pál, Sipos Balázs és Zeidler Miklós közreműködésével, online: http://mek.niif.hu/05200/05284/05284.htm\#b222, 13 January 2012; Kincses Nagy Éva, “A turáni gondolat”, in: Östörténet és nemzettudat 1919-1931. Kempelen Farkas Digitális Tankönyvtár, http://www.hik.hu/tankonyvtar/site/books/br44/cho7.html, 22 December 2007.

43 The agrarian/diplomat Alajos Paikert (1866-1948) founded this society in 1910 (officially 1911). For a detailed history of this society, see Farkas, "Turánizmus", pp. 56-66.

Lederer György, "A magyarországi iszlám újabb kori történetéhez, I rész”, in: Keletkutatás, Vol. 3 (1988 ősz), pp. 29-49, here: pp. 33f. Tibor Balla, "Ada-Kaleh szigete osztrák-magyar fennhatóság alatt, 1878-1918”, in: Hadtörténeti Közlemények, Vol. 112, n. 1 (1999), pp. 21-52. Imre Karácsony arranged this invitation after meeting with the Şeyh ül-Islam. Cf. letter dated 14 May 1924, from Abdul Latif to the Prime Minister, 14. csomó, 54. tétel, K28, MOL. Cf. also news issued by the Hungarian Telegraph Office, dated 9 April 1909, in Box 35, MFM. Nizam Önen, "Budapeşte'de Bir Türk İmam: Abdüllâtif Efendi'nin Hayatı", in: Toplumsal Tarih, n. 160 (Nisan 2007), pp. 78-81; Lederer, "A magyarországi iszlám újabb kori történetéhez, I. rész", p. 34; Udvarvölgyi Zsolt, "A magyar iszlám vallásszociológiája", MA-thesis, ELTE Szociológiai Intézet, Budapest, 1998. Online: Terebess Ázsia E-Tár, http:// terebess.hu/keletkultinfo/udvarvolgyi.html, 11 February 2012.

46 Romsics Ignác, “A magyar birodalmi gondolat”, in: Múltról a mának (Budapest: Osiris, 2004), pp. 122-158.

47 Letter dated 17 October 1912, Germanus to ? in 1. csomag, 1. csomó, P1384, MOL.

48 "Secretaire honoraire de la Société Turanique en Hongrie", Letter of Recommendation, dated 6 July 1915, by Comte Khuen-Héderváry, in Box 36, MFM. 
faith, 'Abd al-Bahā', in Budapest. ${ }^{49}$ It seems that at this time he was categorized as a student of "the swindler" Vámbéry, who was a household-name in academia, as opposed to "the scholar" Goldziher. This pre-WWI social life forms the context of the young teacher.

\section{Hungarian Orientalism and Germanus during WWI}

Given the military alliance between the Ottoman Empire and the AustroHungarian Monarchy, Hungarian institutions concerning "the Orient" mushroomed from 1914. Among organizations such as the Centre of Oriental Economics, the Hungarian Cultural Centre of the Orient (the former Turan Society), and the Hungarian Research Institute in Istanbul, ${ }^{50}$ a forgotten charity foundation, "A Vörös Félhold Támogatására Alakult Országos Bizottság" (National Committee for the Support of the Red Crescent, VFTAOB), ${ }^{51}$ organized lectures on Middle Eastern topics.

They involved the professors of the Oriental Academy, whose fee was donated to charity. ${ }^{52}$ The chief speaker was Kúnos who, by default, also recommended Germanus. Apart from Budapest, they held lectures in Szabadka, Kassa, Beszterce, Lőcse, Nyírbász and Szeged. Germanus lectured in Lőcse (modern Slovakia) in March 1915 on "Turkish-Hungarian friendship". ${ }^{53}$ In addition, he had already volunteered for and been enlisted in the Hungarian Royal Prime Ministry's Press Division in 1914, ${ }^{54}$ though no trace of his activity in such a capacity has been found. ${ }^{55} \mathrm{He}$ was able to continue teaching at the Oriental

49 Lederer György, “A magyarországi iszlám újabb kori történetéhez, II rész", in: Keletkutatás, Vol. 4 (1989 tavasz), pp. 53-72, photograph p. 64 and text p. 67. Cf. also Goldziher, Napló, p. 324 .

$50 \quad$ In general, cf. Farkas, “Turánizmus”, pp. 68ff.; Goldziher, Napló, pp. $346 f$.

$5^{1} \quad$ The Committee was established upon the urge from the Ottoman "Red Crescent Society" in the Hungarian Parliament with the active support of Prime Minister István Tisza in December 1914, under the leadership of Count Károly Khuen-Héderváry. Cf. Gróf Tisza István Összes Munkája, 4. sorozat, 2. kötet (Budapest: Franklin Társulat - Magyar Tudományos Akadémia, 1924), p. 367 .

$5^{2}$ Letter dated 16 January 1915, to Kúnos Ignácz igazgató from Vörös Félhold Támogatására Alakult Országos Bizottság, Box 1914/15, KAIH, BCEL.

53 Letter dated 15 February 1915, "Alispán" to Kúnos, Box 1914/15, KAIH, BCEL. Cf. also a letter dated Lőcse, 21 February 1915, "Alispán” to Germanus, Box 36, MFM.

54 Letter dated 27 October 1914, from Magy. Kir. Miniszterelnökség (?) to Germanus, Box 36, MFM.

55 The Prime Ministry Press Office does not mention his name in 1914/5, cf. A Miniszterelnökség központilag iktatott iratai, 1032 csomó, IV. res tétel, K26, MOL. 
Academy (and until 1915 at the Theological Academy). ${ }^{56} \mathrm{He}$ was promoted from "language teacher" to "instructor" at the Oriental Academy. ${ }^{57}$ In fact, Germanus was excused from military service throughout the war. ${ }^{58}$

VFTAOB chose Germanus for war-related missions in the Ottoman Empire in 1915 and 1918, which he vividly described later. ${ }^{59}$ Given the documents, his romantic narratives remain hazy. In July 1915, he obtained a French recommendation letter from Count Khuen-Héderváry, stating that "Prof. Germanus [...] va de la part de notre Comité Hongrois pour le Croissant Rouge Ottoman à Constantinople en mission spéciale" (original italics). ${ }^{60}$ Moreover, in September 1915, Kúnos petitioned the Ministry of Education for a sabbatical in the Ottoman Empire on behalf of Germanus for "unknown reasons but a longer stay in the region to be researched may bring many advantages". ${ }^{61}$ The Ministry granted a "six-month research trip"62 immediately but Germanus returned by October $1915 .{ }^{63} \mathrm{He}$ was sent to Istanbul again in March 1918 to manage the guest concerts of the Hungarian "honvédzenekar" (military music band), whose income went to charity and also towards the reconstruction of the Gül Baba Mosque in Budapest. ${ }^{64}$ Both trips were related to state interests, intended to strengthen the cordial relations between (late-Ottoman) Turks and (late-Habsburg) Hungarians.

\section{The Academic Orientalist during WWI - "iszlamológia"}

The year 1915 saw the seeds of an idea that was to captivate Germanus for the rest of his life. On his return from Istanbul, he submitted to the Oriental

56 Papés László and Bucsay Mihály (eds.), A Budapesti Református Theológiai Akadémia története, 1855-1955 (Budapest: A református egyetemes konvent sajtóosztálya, 1955), p. 200. Letter dated 5 March 1915, from Minister of Education to "Keleti Kereskedelmi Akadémia Felügyelő Bizottsága”. Box 1914/15, cf. also letter dated 17 April 1916, from Kúnos to Ministry, Box 1916/17, KAIH, BCEL.

58 Based on the Academy's request that "the teaching of Arabic and Turkish cannot be done by any other professor". "Fölmentési javaslat", no. 312/914, and exemption dated 16 February 1915, to Kúnos from Ministry, both in Box 1914/15, KAIH, BCEL. In 1917, Germanus was again exempted from military service. Letter dated 6 May 1917, Box 1916/17, KAIH, BCEL.

59 Germanus, “A félhold fakó fényében", pp. 84-101.

$60 \quad$ Letter dated 6 July 1915, Box 36, MFM.

61 Letter dated 15 September 1915, from Kúnos to Ministry, Box 1914/15, KAIH, BCEL.

62 Letter dated 16 September 1915, from Ministry to Kúnos, Box 1914/15, KAIH, BCEL. Cf. the previous argument of having no other teachers!

63 Letter dated 17 October 1915, from Kúnos to Ministry, Box 1914/15, KAIH, BCEL.

64 Letter dated 7 March 1918, from Secretary of State to Kúnos, Box 1918/19, KAIH, BCEL. 
Academy's Board of Trustees a petition to establish a Department of Islamic Studies ("iszlamológiai tanszék"). In this letter, Germanus argued that the Academy should create the new department to teach "the development of the Muslim faith, the new [contemporary] history of the Muslim states, and Muslim religious law". With this "natural progress", the students would not only study Turkish and Arabic as the languages of Muslims but also "their way of thinking, customs, habits, prejudices, etc." ${ }^{\prime 5}$ This offer seems to be born in the prevailing atmosphere of victory over Serbia and out of the Hungarian imperial idea. ${ }^{66}$ There is no indication that the proposal was ever considered although, in March 1916, he delivered a lecture entitled "Az iszlamológia", 67 and this title figured among his courses in the academic year 1916/17. ${ }^{68}$ Considering that Goldziher who taught at the University was the recognized founder of modern Islamwissenschaft, Germanus' scheme appears not entirely appropriate.

\section{Against Anthropogeographia}

During WWI Germanus published popular articles about Islam and the Turks. ${ }^{69}$ He also wrote a pamphlet against Turanists, heedless of his earlier attachment to their Society. In this he recognized that

the goal of Turanism is not only to classify mankind on an unscientific basis, but, starting from this classification, to spread in the public sphere the idea of a fictional kinship of peoples who dwell far away from each other and to base political aspirations on this belief. ${ }^{70}$

65 Letter dated 16 December 1915, from Germanus to Magyar Királyi Keleti Kereskedelmi Akadémia Felügyelő Bizottsága, Box 1914/15, KAIH, BCEL.

66 For instance, Paikert Alajos of the Turan Society in August 1915 submitted to the Prime Minister a plan about a "German-Turanian State Confederation" that would include the whole of Eurasia and in which Hungary would be among the great powers. Quoted in Romsics, “A magyar birodalmi gondolat", pp. 121f. and 144f.

67 Classes of the Oriental Academy for the 1916 spring semester. Box 1914/15, KAIH, BCEL.

68 A handwritten note, dated 9 May 1916, Box 1914/15, KAIH, BCEL. Yet in the curriculum for the first semester of academic year 1916/17, only Turkish classes are registered under his name. Sheet dated 10 October 1916, Box 1916/17, KAIH, BCEL.

69 For instance, Germanus Gyula, "Kulturális problémák Törökországban”, in: Magyar Figyelo", Vol. 10, n. 24 (1917), pp. 251-261.

70 Dr. Germanus Gyula, Túrán (Budapest: A szerző saját kiadása [The writer's own publication], 1916), p. 2. 
This provoked a debate with Count Pál Teleki, an MP and leading member of the Turan Society. ${ }^{71}$ In a second pamphlet Germanus' main argument was that the differences and similarities between peoples do not originate from "racial" essences but from their different histories. ${ }^{72} \mathrm{He}$ refuted the relationship between geography and race, concluding that this "anthropogeographia" cannot be based on "natural laws in mathematical formulas". ${ }^{33}$ These publications later provided a solid foundation for his claim to be a fierce anti-nationalist, stating - after WWII and the Holocaust - that his was "the prophet's anxious warning." ${ }^{74}$ Yet, Germanus never again ventured to publish anything that opposed antiSemitism during the 1920s and 1930s, when Turanism, from being a learned elite discourse, became a popular movement, embracing extreme right-wing factions. ${ }^{75}$ Germanus' attempt to instruct Hungarian identity-debates remains an isolated endeavour instead of a consistent ideological stand.

During the war he also formed an attachment with Rózsa Hajnóczy, the daughter of an old Hungarian Christian family, and married her on 31 December 1918. As for his career advancement, despite Khuen-Héderváry's help, Germanus was not promoted further in the academic grade due to the general freeze of appointments. ${ }^{76}$

71 Germanus claims that Pál Teleki engaged in a public debate with him in "academic journals". Germanus, "A félhold fakó fényében", pp. 115f. Teleki indeed (together with another geographer, Jenő Cholnoky) argued that "Túrán” is a geographical concept (in the journal Túrán, no. 1-2 [1918], pp. 44-48). Cf. Farkas, “Turánizmus", pp. 73f.; and also Egey Emese (ed.), A Turán címú folyóirat 1913, 1917-1918, 1921-1944 finnugor mutatója (Budapest: Tinta Kiadó, 2002). Zoltán Szász cites the pamphlet of "Germanusz" in “Turánizmus”, in: Nyugat, no. 16 (1916), electronic version: http://epa.oszk.hu/ooooo/ooo22/nyugat.htm, 16 November 2011.

72 Dr. Germanus Gyula, $A$ Föld és Faj Hatása a Történelemben (Budapest: Franklin Társulat Nyomdája, 1920, written in 1917), pp. $57 \mathrm{ff}$.

73 Ibid., pp. $33^{\text {f. }}$

74 Germanus, "A félhold fakó fényében", p. 97.

75 Farkas, “Turánizmus", pp. 86-95.

76 During 1916, he wished to be promoted from "instructor" to "university lecturer" (rendes tanár). Letter dated 17 April 1916, from Kúnos to Ministry, Box 1916/17, KAIH, BCEL. Refusal dated 4 May 1916, from Ministry to Kúnos, Box 1916/17, KAIH, BCEL. In 1917 his request was again refused. Letter dated 30 October 1917, from the Minister of Religion and Education to Khuen-Héderváry Károly, Box 36, MFM. 


\section{The Communists and Germanus, 1919}

After the war, the short-lived republic of Hungarian Communists (led by Hungarian Jews $)^{77}$ also required Germanus' expertise in 1919. They were sympathetic to the "Oriental idea" and, despite their troops' looting of the Society's rooms in the early days, they supported the Turán Society/Cultural Centre. ${ }^{78}$ After their fall from power, in September 1919, Germanus was called to a hearing. He testified that Tibor Szamuely (the feared leader of the Communist Council's military court) had summoned him to translate propaganda materials into Arabic and distribute them among the Arab soldiers of the French Army in the Balkans. Germanus claimed he merely "pretended" to accept this request, and in fact did not translate anything. ${ }^{79}$ Thus, in October 1919, he was cleared of the charge of cooperating with the Communists. ${ }^{80}$ Yet, in a more detailed letter two years later, he described events differently. In this second version, Szamuely had threatened him with hanging if he refused to cooperate, and ordered him to go immediately to South Hungary, accompanied by soldiers, to disseminate propaganda materials. He managed to escape and flee to Kecskemét. Despite the Communists' arresting relatives of his in the city, he remained there for three weeks. He only returned to Budapest because he "was worried" about his flat. Through a series of mishaps, he was forced publically to announce that he had visited South Hungary with Communist soldiers. After that, he again fled. Thus runs his second account of this forgotten episode. ${ }^{81}$ His missions in Istanbul and this Communist adventure illustrate the use of Orientalists by Hungarian wartime regimes.

\footnotetext{
77 William O. McCagg, "Jews in Revolutions: The Hungarian Experience", in:Journal of Social History, Vol. 6 (1972), pp. 78-105.

78 Farkas, "Turánizmus", p. 117.

79 Copy of minutes taken at a public hearing, dated 30 September 1919, containing Germanus' confession, 6/b 35, KKDH, BCEL.

$80 \quad$ Copy of a letter dated 17 October 1919, 6/b 35, KKDH, BCEL.

81 A report by Germanus, dated 3 October 1921, 6/b 35, KKDH, BCEL. The document survived as part of a court process against a teacher, Dr. Géza Birkás, who accused Germanus of Communist cooperation, letter dated 8 November 1921, from the Dean to the Minister, 6/b 35, KKDH, BCEL. Germanus signed a student's (Ferenc Szanter) certificate in March 1919 in Budapest, Box 1918/19, KAIH, BCEL.
} 


\section{Post-WWI Adjustment of Hungarian Orientalism}

Goldziher died in 1921. The appointment of a former student of his, the controversial Mihály Kmoskó (1876-1931), as his successor in 1923, ${ }^{82}$ restored a Catholic priest to the state university position in Semitic philology (the ex-priest Hatala had this chair before Goldziher). Goldziher's Hungarian Jewish students, such as Bernard Heller (1871-1943), continued to teach Semitic philology at the Jewish Seminary, while Josef (de) Somogyi maintained Goldziher's scholarly legacy. ${ }^{83}$ A gifted student in Turkish, Gyula Németh (1890-1976) was to become an internationally known Turkologist, being appointed to Vámbéry's vacated chair as extraordinary (1916), finally ordinary professor (1918) at the university. ${ }^{84}$ His career runs parallel to that of Germanus.

The arrival of a new academic generation coincided with the post-war kingless Hungarian Kingdom's educational reorganization. The poor nation-state required fewer Orientalist students and could finance fewer visiting Muslim students. ${ }^{85}$ The Oriental Academy melted into the Faculty of Economics as its Oriental Institute at the reorganized Royal Pázmány Péter University of Budapest. ${ }^{86}$ Germanus was appointed ordinary professor there in February 1922, on a promise that he would be promoted within six months. ${ }^{87}$ Kúnos retired in June 1922. Count Pál Teleki - following his stint as Prime Minister took over the position of Dean of the Faculty of Economics. And he kept the

82 Kmoskó, after the Communist dictatorship of 1919, became an ardent anti-Semite (although he later seemingly reconciled with the Jews). Ormos István, "The Correspondence of Ignaz Goldziher and Max Herz", in: Apor and Ormos (eds.), Goldziher Memorial Conference, pp. 159-201, here p. 170, n. 46.

83 Julius Németh, "Die Orientalistik in Ungarn 1938”, in: Káldy-Nagy (ed.), The Muslim East, pp. 11-22, here pp. 12f.

84 EIr, "Németh, Gyula" (András Bodrogligeti). http://www.iranicaonline.org/articles/nemethgyula, 24 December 2012 (Németh's birthdate is wrong).

85 Note to the Prime Minister from Keleti Kultúrközpont, dated 25 November 1918, 209 csomó, 412. tétel, K28, MOL.

86 The Oriental Academy surrendered its assets to the Faculty of Economics on 24 May 1921, "Jegyzőkönyv", Box 1920/21, KAIH, BCEL.

87 Letter dated 11 February 1922, in 5/b 4 I/88o, KKDH, BCEL. Kúnos - who remained Institute director for its first year - asked for Germanus' promotion, on the argument that he also taught at the Theological Academy and that his promotion had been delayed only by the war. Letter dated 3 May 1922, from Kúnos to "Méltóságos Uram" (Teleki?), 5/b 4 I/88o, KKDH, BCEL. 
directorship of the Oriental Institute to himself. ${ }^{88}$ Thus, by 1923, Christian Hungarians had replaced Hungarian (assimilated) Jews in the highest state positions of Arabic and Turkish Studies at the university (Németh took Vámbéry's chair, Kmoskó took Goldziher's, Teleki became director instead of Kúnos or Germanus).

\section{"I Am Not Completely Useless, Am I?": The 1920s}

In the new educational system Germanus was reduced to teaching English at the Oriental Institute. But he was not prepared to accept such a limited role. In a memorandum, he suggested reorganizing the curriculum, giving prominence to a course he proposed, entitled "The History of Oriental People", and including his name among the language teachers as preceptor in Arabic (!) ${ }^{89}$ This suggestion drew no response, perhaps because Germanus had missed some of his English classes without notice, which sparked a university investigation. ${ }^{90}$ During the process (which eventually resulted in an official reprimand by the Dean), he defended himself citing heart problems and referring to his poverty which drove him to offer private classes. ${ }^{91}$

Yet, instead of freeing up his time, Germanus offered his free services again to the Calvinist Theological Academy. ${ }^{92}$ Furthermore, he introduced a prize for an essay-writing competition among the students of theology. ${ }^{93} \mathrm{~A}$ year later, Germanus requested a "title" from the Theological Academy as compensation for his services. Not only did the Calvinist professors bluntly refuse him but the students also failed to submit a single entry to the essay competition. ${ }^{94}$ After

88 "The Faculty will not take a position until Teleki returns because His Excellency reserves the right to make all decisions on issues related to the Oriental Institute." Response to a petition in 1924, 5/b 6 I/1735, KKDH, BCEL.

89 Memorandum, submitted to the Ministry of Education, undated by Gyula Germanus, $5 / \mathrm{b}$ 7 V/613, KKDH, BCEL. A note dated 22 September 1922 accompanies the Memorandum.

9o Letter dated 30 January 1923, written to the Faculty by an unknown individual (illegible signature, probably Dengl János), in 5/b 5 485, KKDH, BCEL.

$91 \quad$ Letter dated 15 February 1923 , Germanus to ? (the Dean?), accompanied by medical proof dated 14 February 1923, in 5/b 5 485, KKDH, BCEL.

92 "Jegyzőönyv", dated 22 September 1923: Germanus offers "again" to teach the history of the Koran and Arabic. Tanári ülések Jegyzőkönyvei, 1922-1928, RL.

93 The topic being "Christian and Jewish sources of the religion of Mohamed". "Jegyzőkönyv", dated 11 September 1924. Tanári ülések Jegyzőkönyvei, 1922-1928, RL.

94 “Jegyzőkönyv", dated 5 December 1924. Tanári ülések Jegyzőkönyvei, 1922-1928, RL. The Academy could only offer the title "theológiai magántanár" (professor of theology) but one had to be qualified as a pastor before obtaining such a title. 
this double failure, he abandoned his teaching post at the Theological Academy. ${ }^{95}$

Simultaneously he sought to strengthen his weak position at the Oriental Institute. By September 1923, he was already teaching Arabic free of charge, as evidenced in a note in which he proudly poses the rhetorical question, "I am not completely useless, am I?" ${ }^{\prime 6}$ In June 1924, he re-submitted an improved proposal to teach the "Cultural History of Oriental People" (again refused). ${ }^{97}$ This was his third, vain attempt $(1915,1922,1924)$ to teach a historical subject rather than languages. Next, his English classes were stopped. ${ }^{98}$ And in 1925 he was downgraded from university lecturer to high school teacher in the salary scale. ${ }^{99}$

But Germanus did not give up. He published a Turkish Grammar in Hungarian $^{100}$ and also applied to work as an official translator (in Turkish and Arabic) at the Justice Court of Budapest in $1926 .{ }^{101}$ In 1927 he requested to be restored to the university salary grade. ${ }^{102}$ Germanus, failing to conduct research, was buried at the Oriental Institute of the Economics Faculty as a minor language-teacher, on the margins of academia. Gyula Németh, in his 1928 survey of Hungarian Orientalism, does not mention him at all. ${ }^{103}$ As a final blow, Németh established the proper Department of Turkish Studies and Hungarian Ancient History in the Humanities Faculty in 1930 without Germanus.

95 “Jegyzőkönyv", dated 8 October 1925. Tanári ülések Jegyzőkönyvei, 1922-1928, RL.

96 Letter dated 29 September 1923, Germanus to ?, in 5/b 5485 , KKDH, BCEL.

97 Proposition of Germanus to the Dean (Teleki), dated 11 June 1924, in 5/b 6 I/1735, KKDH, BCEL.

98 Letter dated 11 October 1924, from the Faculty (Dean?) to ?, 5/b 6 I/1735, KKDH, BCEL.

99 A note by the Dean, dated 16 February 1926, and the complaints of Germanus, dated 3 January 1927, both in 6/b 35, KKDH, BCEL.

100 Germanus Gyula, Török nyelvtan - Gyakorlókönyv olvasmányokkal az arab-török írás elsajátítására (Budapest: Lingua, 1925).

101 Note dated 8 February 1926, 6/b 35, KKDH, BCEL, in which Germanus refers to having already worked as a translator at the Court of Budapest, about which there is no data so far.

102 Letter dated 9 May 1927, Germanus to Dean, 6/b 35, KKDH, BCEL.

103 Németh Gyula, "Akadémiánk és a keleti filológia”, in: Budapesti Szemle, n. 611 (1928), pp. 80-95. 


\section{The PEN Club and Disenchantment with Turkology}

Literature offered new perspectives. The Hungarian branch of the PEN Club was founded in spring 1926 in the presence of its British honorary-president, John Galsworthy. With good English, Germanus acted as interpreter for Galsworthy and his wife in Budapest, and, given his availability and knowledge of languages, was elected secretary of the Hungarian PEN. ${ }^{104}$ And in June 1926, the Ministry (of Education?) financed a trip to republican Istanbul. ${ }^{105}$ As he later recalled, his heart belonged to "a Turkey of my youthful dreams whose pale crescent now is overshadowed by a new sun, for good". 106 However, Németh's dominance in the university may also be among the reasons for his disenchantment with secular Turkey.

As a coincidence, whose importance we shall see soon, the Indian poet Rabindranath Tagore arrived in Budapest during his European tour in the autumn of that year. ${ }^{107}$ The Hungarian PEN gave a dinner in his honour on 30 October 1926. It is here that Germanus, back from a PEN-dinner in Sofia, ${ }^{108}$ probably met and spoke with Tagore. ${ }^{109}$ Before leaving Hungary, Tagore promised: "I remain really very grateful for everything." ${ }^{\text {"10 }}$ Germanus continued being secretary of the Hungarian PEN-Club until 1943 and participated in many PEN-Club gatherings in Belgrade, Sofia, Oslo, Dubrovnik, and Edinburgh. ${ }^{111}$

104 Manuscript, entitled "Emlékezéseim a PEN Clubra" (My Recollections of the PEN Club, 9 typewritten pages), dated 12 February 1966, Box 28, MFM. Cf. also Germanus, "A félhold fakó fényében", p. 103.

105 Note dated 26 June 1926, 6/b 35, KKDH, BCEL. In his memoirs, he writes that, thanks to his "book", the Government of Mustafa Atatürk invited him to new Turkey in 1928: Germanus, "A félhold fakó fényében", p. 103. The book in question is an article, Germanus Gyula, "A török forradalom", in: Budapesti Szemle, n. 604 (March 1928), pp. 342-371, that was also published in French in three parts during March-April-May 1928, as Jules Germanus, "Pensées sur la Révolution Turque", in: Revue de Hongrie, Vol. 21, n. 27-28-29. Yet, in another (unpublished) memoir, he dates his trip to 1927. "Emlékezéseim a PEN Clubra", dated 12 February 1966, Box 28, MFM.

106 Germanus, "A félhold fakó fényében", p. 107.

107 Bangha Imre,Jöttem a Gangesz partjairól - Bengáli kultúra és magyar irodalom (Budapest: L'Harmattan, 2011), pp. 249-303.

108 Cf. Magyar Távirati Iroda, 11 October 1926, 13 pm issue. "Szófiából jelentik".

109 Bangha Imre, "Tagore magyarországi látogatása”, in: Felföldi Szabolcs (ed.), Abhivādana: tanulmányok a hatvanéves Wojtilla Gyula tiszteletére (Szeged: SZTE Ókortörténeti Tanszék, 2005), pp. 33-61.

110 Quoted in Bangha, "Tagore magyarországi látogatása", p. 53.

111 "Emlékezéseim a PEN Clubra", dated 12 February 1966, Box 28, MFM. 


\section{Shantiniketan}

Despite his lack of academic success, his good international network helped Germanus in an unusual way. Among Tagore's entourage in 1926 was P.C. Mahalanobis, Secretary General of the Visva Bharati University in Shantiniketan, accompanied by his wife. The Mahalanobises and the Germanuses met in Budapest. ${ }^{112}$ In 1928, either Mahalanobis or Tagore invited Germanus to apply for a new chair in Islamic Studies (established by the Nizam of Hydarabad). ${ }^{113}$ Germanus indeed applied on 1 November 1928. Mahalanobis, who was also on the selection committee, ${ }^{114}$ notified him that he was expected to "organize Islamic research and advanced studies", and to "help our students with German and French". 115 Being appointed on a salary of $£_{35}$ per year Germanus asked the Hungarian Ministry of Education for additional financial help. He translated his tasks for the Hungarians as follows:

to chair the Department, to organize a library, and to collect primary sources. The object [of the teaching/research] is the history of Mohammedanism and the cultural-historical role of Islam in India, besides lecturing on Arabic philology. Apart from this narrowly defined work at the department, naturally I want to do research about the traces of the rule of peoples related to Hungarians (Ghaznevids, Baberids, Moghuls [!]) in North India, furthermore about the monuments of the old Hun Empire and about the documents concerning Hungarian history in the archives of Muslim princes. ${ }^{116}$

Despite his obvious effort to conform to the Hungarian nationalist discourse, Germanus did not receive any additional support for his tenure in India, but his

"My wife and I shall look forward to meeting you in our own country. With kindest regards to Mrs. Germanus and yourself." Letter dated 29 November 1928, from P.C. Mahalanobis to Germanus, Box 36, MFM.

113 "Magyar tudóst hívtak meg Tagore egyetemére", Az Est, 1928 november 17, 2. Germanus stated that he was "officially invited to India" (Germanus, "A félhold fakó fényében", p. 115.), by Rabindranath Tagore (Germanus, Allah Akbar!, p. 25).

114 Bangha, Jöttem a Gangesz partjairól, p. 135.

115 Letter dated 29 November 1928, from P.C. Mahalanobis to Germanus, Box 36, MFM.

116 Letter dated 8 January 1929, from Germanus to the Minister, in Germanus Gyula személyi dossziéja, 490 d, K636, MOL. 
leave was agreed as a paid three-year sabbatical. ${ }^{117} \mathrm{He}$ and his wife left Budapest during spring 1929. ${ }^{118}$

They reported about their three years in India in three texts: a popular romantic novel, entitled Fire in Bengal, published under the name Rózsa Hajnóczy; ${ }^{119}$ Germanus' bestseller Allah Akbar! ${ }^{120}$ and the late semi-autobiography, already referred to. ${ }^{121}$ These texts show a mixture of the white man's arrogance with doubtful remarks about research. As for his Indian evaluation, the university authorities wrote that Germanus "receives a 400 rupee salary and does nothing". ${ }^{122}$ Meanwhile, his Hungarian salary was not being paid, ${ }^{123}$ and Germanus begged for compensation in the coming years. ${ }^{124}$

\section{The Second Conversion}

In India Germanus acquired a new identity. The University of Delhi invited him to deliver lectures that winter. ${ }^{125}$ According to his narration, he became a Muslim on 19 December 1930, on a Friday, in the Great Mosque of Delhi. After the khutba, he gave a short speech, which he began in Arabic (!), about having come to India as a seeker of knowledge, about the place of Islam in the history of humankind, the decline of the Muslim peoples, and their possible renaissance. In the enthusiastic audience a friend hurriedly led him out, as Germanus remembered, lest the cheering crowd squeeze him. ${ }^{126}$ He took the Muslim name

117 Letter dated 18 February 1929, from Minister of Finance to Minister of Education and Religion, in Germanus Gyula személyi dossziéja, in 490 d, K636, MOL. Telegraph dated 30 February 1929, 6/b 35, KKDH, BCEL.

118 In his absence, Somogyi was invited to teach Turkish and Arabic at the Oriental Institute in his place. Letter dated 15 May 1929, from the university to József Somogyi, 6/b 35, KKDH, BCEL.

119 G. Hajnóczy Rózsa, Bengáli tüz (Palatinus-Magyar Földrajzi Múzeum, 2002, at least the 12th edition - unnumbered).

120 Germanus, Allah Akbar!, pp. 25-72.

121 Germanus, "A félhold fakó fényében", pp. 115-133. Bangha, Jöttem a Gangesz partjairól, pp. 137-146 gives a detailed evaluation of the couple's life in India.

122 Letter to Tagore, 1930, quoted in Bangha,Jöttem a Gangesz partjairól, p. 140.

123 Note dated 1 April 1930, in Germanus Gyula személyi dossziéja, in 490 d, K636, MOL.

124 Letter dated 24 June 1930, Germanus (from Shillong) to Magyary, and letter dated 9 September 1930, Germanus to Teleki, in Germanus Gyula személyi dossziéja, in 490 d, K636, MOL.

125 Germanus, Allah Akbar!, p. 27.

126 G. Hajnóczy, Bengáli tüz, pp. 516ff. quotes her husband's letter concerning his conversion in Delhi. Since Germanus travelled to Delhi in "the middle of December 1930" and since 
'Abd al-Karim. There is no mention of the shahäda, the compulsory act of conversion to Islam.

There are hints that he got the idea of conversion only in order to visit Mecca and Medina. In addition, he recognized in India that, despite having received his summa cum laude in Arabic twenty-three years earlier, he still did not understand the Koran. This crisis manifested itself in insomnia: "My brain was full, but my soul was thirsty. I had to abandon everything, I had to leave my knowledge behind, in order to get it back from an internal catharsis." ${ }^{27}$ Once, even the Prophet Muhammad visited him in a dream and they conversed in Arabic. Germanus, ashamed of his pronunciation, asked the Prophet: "I cannot solve the mysteries of the Arabic language, not to mention the endless secrets that are veiled. Help me, Mohamed, oh, messenger of Allah, help me!"128 This crisis led him to the conclusion that he could not understand "the Muslim soul from books, in order to understand that [the Muslim soul], one has to live through [as if he were a Muslim]". On the other hand, his narrative may refer to a possible act of $d a^{c} w a$ by Muslim friends in Delhi: Sa'īd Anșārī; a certain Aslam; the "wahhābl" 'Abd al-Hayy; and another person called Sa'd. It was in their company that Germanus attended the Mosque. He was lead to the minbar by 'Abd al-Hayy and, after his speech, it was Aslam who led him out of the crowd. ${ }^{129}$ Islam brought him other contacts, such as Taqī al-Dīn al-Hilālī, the famous Muslim revivalist. ${ }^{130}$

Muslims in Hungary were reluctant to accept his conversion. Even today, his sincerity is often doubted. A detail that may support the doubts, appears in the following year, 1931. When asking the Hungarian Ministry of Education to finance his trip to Mecca, Germanus wrote (still from India): "I have to disguise myself, too, to venture my dangerous trip acting like a Muslim" ("nekem is álruhában, mohamedánságot színlelve kell veszélyes utamat megkisérelni", my emphasis). ${ }^{31}$ This letter was written only nine months after his impassioned speech at the Great Mosque of Delhi. Yet, this statement should be seen in the context of interwar Hungary, where the government wanted to create a strong Christian middle class. This was especially the mission of his dean, Count Teleki,

when his wife received this letter she was preparing for Christmas, it appears likely that the speech occurred on Friday 19 December 1930. I am grateful to Katalin Puskás for drawing my attention to this detail.

Germanus, “A félhold fakó fényében”, p. 126. G. Hajnóczy, Bengáli tüz, p. 516.

Germanus, Allah Akbar!, pp. 28f.

Germanus, Allah Akbar!, pp. 34f.

"Risālat al-Duktūr Jarmānūs", al-Fath, 14 Jumādā al-Ūlā 1351 (15 September 1932), p. 5 .

Letter dated 2 August 1931, from Germanus to Ministry of Education, in Germanus Gyula személyi dossziéja, in 490 d, K636, MOL. 
to whom Germanus, at the same time as his letter to the Ministry of Education, sent a note that "this pretence under no circumstance impacts upon my Christian devotion and religious faith".132

\section{The Beginning of a Career, 1932-1934}

The Germanuses returned to Hungary in March 1932. ${ }^{133}$ Germanus' first order of business was to fight for his withheld salary, in which endeavour he failed. ${ }^{134}$ Second, he started to prepare for his pilgrimage (cf. below) and, third, he actively sought recognition. He was curator of the Library of the Oriental Institute in 1933-1934, ${ }^{135}$ published an article on the centenary of Vámbéry's birthday, ${ }^{136}$ and also wrote articles for the journal Islamic Culture, whose editor-in-chief was Marmaduke Pickthall (another Muslim Orientalist). ${ }^{137}$ His main scholarly activity was the translation of the Koran into Hungarian, perhaps inspired by Pickthall's English translation (1930), but Germanus never finished his Hungarian one. While turning himself slowly into a Muslim Arabist, however, he faced unexpected troubles.

\section{Germanus and Muslims in Hungary in the 1930 s}

By the 1930s, two individuals were fighting for recognition by the Hungarian state as the "main priest of Muslims in Hungary": the imam Abdul Latif, who had arrived in 1909, and "Durics Huszein Hilmi" (as he was called in Hungarian,

132 Letter dated 3 August 1931, from Germanus to the Dean (Teleki), in Germanus Gyula személyi dossziéja, in 490 d, K636, MOL. Cf. Balazs Ablonczy, Pal Teleki (1879-1941): The Life of a Controversial Hungarian Politician (Boulder: East European Monographs, Budapest: Institute of Habsburg History, 2006).

133 Letter dated 20 January 1932, Dean to the Ministry, and letter dated 31 March 1932, Dean to the Ministry, both in Germanus Gyula személyi dossziéja, 490 d, K636, MOL. Cf. also the letter of Germanus to the Dean, dated 21 December 1931, 6/b 35, KKDH, BCEL.

134 The final refusal was based on the argument that such an exception would be "unfair" to those Hungarian scholars who lost years too, remaining in the ex-territories of historical Hungary. Cf. all refusals in Germanus Gyula személyi dossziéja, 49o d, K636, MOL.

135 Report of Germanus to Dean of Faculty, dated 15January 1934, IV 1193 /33-44, 5/b 26 doboz, KKDH, BCEL.

136 Germanus Gyula, "Vámbéry Ármin", Nyugat (December 1932), electronic version, http:// epa.oszk.hu/ooooo/ooo22/o0548/17157.htm, 16 November 2011.

137 Dávid, “A Bibliography”, pp. 257f.; art. 45-46. 
1887-1940), a Bosnian imam to the Muslim soldiers in the Austro-Hungarian army, who had remained in Hungary after WWI. ${ }^{138}$ Imam Abdul Latif found himself without support between Christian Hungary and secularist Turkey in the 1920s. Yet, he managed to gain the grudging recognition of the post-WWI Hungarian authorities. ${ }^{139}$ On the other hand, Hussein Hilmi and his post-war Muslim community were supported by a number of (probably Turanist) Hungarians who opted for the Bosnians instead of Abdul Latif. Their preference was not unrelated to the fact that Hussein Hilmi had fought for Hungarian interests after 1918 and had accepted Hungarian citizenship. ${ }^{140}$

The Türbe of Gül Baba became the touchstone of their rivalry. This tomb of the patron Sufi saint of Buda (a dervish who died when Sultan Sulayman I conquered the city) had been the symbol of Turkish-Hungarian friendship, and many expected to develop this site a place of popular pilgrimage. ${ }^{141}$ Hilmi's supporters established the Gül-Baba Kulturkomité (Cultural Committee for Gül Baba [Tomb]) as a representative of Islam in Hungary in 1932. They sought not only to restore the Tomb of Gül Baba but also planned to establish a Muslim College in Budapest and invite dervishes there. The Hungarian authorities did not recognize the Kulturkomité as an official religious denomination, so Hilmi instead appealed to worldwide Muslim activism for funding. Thus, he travelled to Egypt, Syria, Palestine, Iraq, and India with the support of the Pan-Islamist Shakīb Arsalān. ${ }^{142}$

Germanus, as a Hungarian Muslim and an "expert", became a go-between between the Kulturkomité and Abdul Latif. He attempted to arrange meetings with the imam on behalf of the Committee, discussing the leadership of the newly formed Muslim community, ${ }^{143}$ and advised Hilmi that, according to a 1916 law, only a Hungarian citizen could be named leader of the community (Abdul Latif remained a Turkish subject). ${ }^{144}$ In consequence, Germanus was

138 Lederer, “A magyarországi iszlám újabb kori történetéhez, II. rész", pp. 55-65.

139 Cf. his letters written to the Ministry of Education and Religion between 1920 and 1927, 14. csomó, 54. tétel, K28, MOL.

140 Lederer, "A magyarországi iszlám újabb kori történetéhez, II. rész", p. 53.

141 Ágoston Gábor and Sudár Balázs, Gül baba és a magyarországi bektasi dervisek (Budapest: Terebess Kiadó, 2002), online: http://terebess.hu/keletkultinfo/gul.html, 30 January 2012.

142 Lederer, “A magyarországi iszlám újabb kori történetéhez, II. rész", pp. 6uff.

143 Letter dated 26 September 1935, Germanus to "Polgármester" (Mayor of Budapest), "több ízben tárgyaltam Abdul Latiffal a Gül-Baba bizottság megbízásából [...] kérésemre pathologikus módon reagált [...] önmagából kikelve bosszút forralt." Box 35, MFM. ("I had discussions with Abdul Latif on behalf of the Gül-Baba committee [...] hearing my request he reacted in a pathological way [...] completely beside himself he planned revenge.")

144 Germanus, Allah Akbar!, pp. 73f. Cf. also Lederer, "A magyarországi iszlám újabb kori történetéhez, II. rész", p. 56 . 
cast out of favour with the angry imam. Abdul Latif may have composed a letter to the Egyptian Consul in Vienna reporting that Germanus was only pretending to be a Muslim, ${ }^{145}$ and perhaps sent another letter to the sheikhs of al-Azhar. ${ }^{146}$ He certainly accused "Darwiche Dourich Hussein" of being "un instrument entre les mains des chrétiens et des juifs". ${ }^{147}$ Abdul Latif also claimed in an Arabic interview later that Germanus was "sometimes a Jew, sometimes a Buddhist, sometimes a Muslim and I do not know what he will be next". ${ }^{148}$ Such statements were dangerous for Germanus both in Saudi Arabia and in increasingly anti-Semitic Hungary.

\section{Egypt and Pilgrimage: Becoming an Arabist}

In 1934-1935, Germanus travelled to Egypt and then to Mecca which he described in his already oft-quoted mixture of travel description, popular science and Orientalist tropes, Allah Akbar! Although he had already tried to embark on his pilgrimage from India in 1931, ${ }^{149}$ only in 1933 did he receive the green light from the Hungarians, to set off on what was deemed "a scientific expedition". He applied to both the Faculty and the Ministry with an ambitious plan to "finish the Koran-translation according to the various legal schools" in Egypt, to undertake the pilgrimage in Mecca, to study manuscripts in Medina and finally to research the "still intact" system of Bedouin tribes in Najd. ${ }^{150}$ Count Teleki supported his request warmly, so Germanus was granted a 1000 pengő scholarship

145 The existence of such a letter was acknowledged by Abdul Latif later, in "Jegyzőkönyv", dated 27 March 1936, Budapest, by "Kuncz Ödön egyetemi ny. r. jog- és államtudománykari tanár prodékán, fegyelmi biztos", in the presence of Gyula Germanus and Abdul Latif, in Box 35, MFM.

146 Abdul Latif denied the existence of this letter, "Jegyzőkönyv", dated 27 March 1936. Another letter from the Hungarian Royal Consul to Dr. István Vonház, Provost, dated $3^{1}$ August 1935 states that "they cannot provide a copy of this letter but Hassanein Bey said informally that Abdul Latif had mentioned in his letter that Dr. Germanus is not a truly devoted Muslim thus it is recommended to behave cautiously with him and to keep a distance". Both in Box 35, MFM.

147 Letter dated 5 May 1933, from Abdul Latif to Le Consul D'Egypte à Vienne; (old system of cataloguing:) 'Ābdīn, Maḥfaẓa 195, Dār al-Wathāiq al-Qawmiyya (Egyptian National Archives).

148 Anonymous article, "al-Islām fì l-Majar", in al-Siyāsa al-Usbūicyya (1937?), press cut in Box 35, MFM.

149 Letter dated 2 August 1931, from Germanus to the Ministry of Education, in Germanus Gyula személyi dossziéja, 490 d, K636, MOL.

150 Letter, undated, Germanus to the Faculty, 6/b 35, KKDH, BCEL. 
from the Ministry. ${ }^{151}$ The Faculty also wrote directly to the Hungarian chargé d'affairs in Egypt, requesting help with finding accommodation in an Egyptian university dormitory because it was "absolutely necessary that he should stay in a pure Muslim Arab environment". 152

Bypassing the Egyptian Embassy in Vienna by using the embassy in London, finally he arrived in Egypt around late September 1934. He had already been in contact with Egyptian writers, among them 'Abd Allāh 'Inān, who became a close friend. ${ }^{153}$ Apart from another confirmed friend, Muhammad Amin Hassūna, ${ }^{154}$ in Cairo, Germanus sought out the company of famous writers: Salāma Mūsa, Maḥmūd 'Abbās al-'Aqqād, Tawfīq al-Hakīm, Maḥmūd Taymūr, Kāmil al-Kaylānī, Muhammad Ḥusayn Haykal, etc. ${ }^{155}$ In addition, he was in contact with famous Muslim revivalists, such as the Indian Muhammad Iqbāl, 156 and al-Hilālī. ${ }^{157} \mathrm{He}$ never mentioned the pilgrimage as a "scientific expedition" in his letters to his Muslim supporters. In Cairo, he gave a lecture in Arabic about Muslims in Hungary at the Jamiyyat al-Shubbän al-Muslimin (Society of Young Muslims) in December $1934 .{ }^{158} \mathrm{He}$ also met the Grand Sheikh of al-Azhar, al-Ẓawāhirī, to ask permission to study there, as had Goldziher before him. When he announced his desire to translate the Koran into Hungarian, the Grand Sheikh sought to thwart him by maintaining that the Koran is untranslatable. Germanus responded, pleading that he only wished to study ("my voice was trembling with honesty", he recounts) so al-Zawāhirī admitted him to alAzhar. Later, he would attribute the softening of the Grand Sheikh's heart to a desire to redeem his bad conscience, having received Abdul Latif's letter and been too quick to judge the Hungarian about whose Muslim pretensions he had been warned. ${ }^{159} \mathrm{Al}$-Zawāhirī was, in fact, seriously opposed to the translation

151 The decision of the Faculty is dated 30 November 1933, 6/b 35, KKDH, BCEL. The decision of the Minister, including the 1000 pengő, is dated 16 February 1934, in Germanus Gyula személyi dossziéja, 490 d, K636, MOL.

152 Letter dated 16 March 1934, from Dean to Pál Förster, chargé d'affairs, 6/b 35, KKDH, BCEL.

153 Germanus, Allah Akbar!, pp. 129-133.

154 Germanus, Allah Akbar!, p. 127.

155 Germanus, Allah Akbar!, pp. 157-180.

156 Letter dated 24 May 1934, from Iqbal to Germanus, in English, Box 36, MFM.

157 Another news about/of Germanus was published in al-Fath 8/392 (12 Muharram, 135327 April 1934), pp. 16ff. I was unable to obtain a copy of this issue. I thank Amr Ryad for this information.

158 Duktūr 'Abd al-Karīm Jarmānūs, ustādh al-ta’rīkh bi-jāmi'at Būdāpast, "al-Islām fĩ bilād al-Majar", 19 December 1934, al-Siyāsa, press cut, Box 35, MFM.

159 Germanus, Allah Akbar!, pp. 135f. 
of the Koran. This issue was a hotly debated political and theological question both in Egypt and among Muslims in general in the late 1930s. ${ }^{160}$

Many in Cairo suspected Germanus of being a British spy, ${ }^{161}$ and this suspicion followed him to Jidda, where he was arrested. Thanks to a letter of recommendation to Abdullah Philby, a trusted advisor of King Ibn Sa ūd, he could continue to Mecca. At the Kaba "the ecstasy of the mob grasped" him in a "spiritual narcosis", so he was unable to "record the scene as a researcher". 162 While visiting Medina, Germanus fell ill and was forced to return to Cairo earlier than planned. Soon thereafter, his description of the hajj appeared in Arabic (translated from the English), advertising the benefits of pilgrimage to the Egyptians. ${ }^{163}$ He had returned to Budapest by June $1935 \cdot{ }^{164}$

\section{"The Pilgrim of Scholarship", 1935-1938}

The late 1930 are crucial in the formation of Germanus' popular image. Suntanned, posing for photographs in Arab robes with his fair hair and blue eyes, he fulfilled the interwar Hungarians' desire for an exotic hero (his relatively short stature was not apparent in the photographs). As he took pains to point out, he was the first Hungarian to have reached Mecca. ${ }^{165}$ As a discursive heir to Vámbéry and Goldziher, in the eyes of the public, he joined the ranks of legendary Hungarian Orientalists. Institutionally, the Economics Faculty with its Oriental Institute merged into a giant new university in 1934 (Magyar Királyi József Nádor Műszaki és Gazdaságtudományi Egyetem). Thus, Germanus was separated from the departments of Humanities where, after the death of Kmoskó (1931), talented linguists, such as Zsigmond Telegdi (1909-1994) in IndoEuropean and Károly Czeglédy (1914-1996) in Semitic philology, would emerge in loose association with Gyula Németh. ${ }^{166}$

\footnotetext{
160 Al-Siyāsa wa-l-Azhar - min mudhakkirāt Shaykh al-Islām al-Zawāhirī (Cairo: Dār al-Shurūq, 2011; orig. 1945), pp. 312-317.

161 Germanus, Allah Akbar!, p. 176.

162 Germanus, Allah Akbar!, pp. 352-356.

163 "Khawāțir 'an al-ḥajj li-l-duktūr 'Abd al-Karīm Jarmānūs", al-Balāgh, 15 May 1935, press cut, Box 35, MFM.

164 Letter dated 7 June 1935, to Minister from Germanus, 490 d, K636, MOL.

165 Germanus, Allah Akbar!, p. 359.

166 Telegdi graduated from the Rabbinical Seminary in 1933 but because of institutional mismatch, and later of anti-Jewish laws, did not get a proper paid position until 1945. Éva Jeremiás, "Preface", in: Zsigmond Telegdi Opera Omnia, 2 vols (Piliscsaba-Budapest: The Avicenna Institute of Middle Eastern Studies - Akadémiai Kiadó, 2006), 1: pp. ix-xxiv.
} 
Back from the pilgrimage, first he sought revenge on Abdul Latif. ${ }^{167} \mathrm{He}$ reported the imam's malicious meddling to the Mayor of Budapest, ${ }^{168}$ to the Minister of Religious and Public Education, ${ }^{169}$ and organized a hearing. ${ }^{170}$ Despite Abdul Latif having already sent a letter in Ottoman Turkish expressing his regrets, ${ }^{171}$ Germanus requested a university process (since Abdul Latif worked as a lector of Turkish) ${ }^{172}$ that ultimately resulted in an official reprimand for the imam. ${ }^{173}$ Germanus was able to use these various means to punish Abdul Latif because he was well connected to various Hungarian private or semi-state societies. The revitalized Cultural Centre of the Orient sought to promote him to the state honorary title "kormányfőtanácsos". The PEN Club, his other important ally, requested that the Government should give Germanus a medal. ${ }^{174}$

This shower of suggestions (although no medal came) was in response to the 1936 appearance of his travel description, Allah Akbar! The Hungarian readership greeted this book with enthusiasm (though some Christian journalists found his conversion a bit hard to swallow). ${ }^{175}$ The book was published in a

167 Arabic letters from 'Inān to Germanus, dated 10 July 1935, 11 August 1935, and 3 November 1935; Box 35, MFM.

168 Letter dated 26 September 1935, Germanus to "Polgármester", Box 35, MFM.

169 Letter dated ? October 1935, to Minister from Gül Baba Committee, Box 35, MFM.

170 "Jegyzőkönyv", dated 29 January 1936 "a Gül Baba Komiténak a Lukácsfürdőben tartott értekezletén, meghivott vendég Abdul Latif", Box 35, MFM.

171 Letter dated 22 Kanūn-i Sānī 1936, Box 35, MFM.

172 Germanus asked Gyula Németh to instigate a university "fegyelmi" process. Letter dated 28 February 1936, Gyula Németh to Dean (?), Box 35, MFM.

173 Letter dated 22 June 1936, to Germanus from Egyetemi Tanács, Box 35, MFM.

174 Letters dated 14 June 1936 and 15 June 1936, 6/b 35, KKDH, BCEL.

175 Praising critiques: Kállay Kálmán, "Magyar könyv az iszlámról: Germanus Gyula: Allah akbar! I-II. Budapest", in: Budapesti Szemle, n. 719 (1937), pp. 121-126; Nagypál István, "Allah Akbar!", in: Nyugat, n. 6, (1937) online: http://epa.oszk.hu/ooooo/ooo22/oo617/19656.htm, 1 February 2012; Kállay Miklós, no title, in: Képes Krónika, Vol. 19, n. 5-6 (1937), p. 25; no author, Germanus Gyula: "Allah Akbar", in: Literatura, Vol. 11, n. 23 (1936), p. 359; Vályi Félix, “Germanus Gyula: Allah akbar”, in: Századunk, n. 9-10 (1937), pp. 393f. Horváth Tibor thought that Germanus made too much compromise for the reading public as a scholar, “Germanus Gyula: Allah akbar!", in: Napkelet, Vol. 15, n. 8 (1937), pp. 539f. Finally, Nyisztor Zoltán, “Germanus Gyula: Allah Akbar”, in: Magyar Kultúra, Vol. 24, n. 2 (1937), p. 61 saw a "tragedy" in the conversion of Germanus as someone who praised Islam vis-a-vis Christianity while Erdősi Károly, “Germanus Gyula: Allah Akbar”, in: Élet, Vol. 28 (1937), p. 186 thought that Germanus' mission was to make "his Muslims friends understand [...] the Christian truth". Kállay Kálmán defended Germanus, saying that the last passage about Athens indicates that he had found "finally Christ", in his article "Germanus Gyula: Allah akbar!", in: Protestáns Szemle, n. 6 (1937), pp. 373ff. As a part of travel-literature, his 
travel series, alongside Lawrence's Seven Pillars of Wisdom and Seabrok's Jungle Ways. The publisher advertised Germanus as the "Pilgrim of Scholarship" and the heir of Vámbéry and Aurél Stein. ${ }^{176}$ Although Allah Akbar! was soon translated into Italian and German, ${ }^{177}$ apart from sporadic mentions, ${ }^{178}$ I could not find any reference to his travels in academic publications. Such Orientalist travel literature was not unique in interwar Hungary - Ervin Baktay, the painterIndologist, had published his travels in India from 1930 onwards, and Lajos Ligeti, the renowned linguist, had written his own account of Mongolia to popular acclaim in 1934. Thus, Germanus' book was in line with the contemporary fashion that one might label "Hungarians discovering the world".

A new medium also contributed to his success: the radio. He lectured on Islamic topics in both Hungarian and English. One of these lectures was even heard in Cairo by Ḥusayn Haykal, the Egyptian writer. He claimed that this radio talk about the pilgrimage was instrumental in his own decision to undertake the hajj..$^{179}$ Germanus' fame also captivated the young: it is from this time that we have personal recollections from his (surviving) students, who heard him in the radio or read his book. ${ }^{180}$ In addition, using a PEN Club congress in England, Germanus reconnected with the University of Oxford. ${ }^{181}$ Now, he merited a mention in Gyula Németh's 1938 survey of Hungarian Orientalism, as a Semitist (!). ${ }^{182}$ It is this popularity that would be remembered after the Second World War.

canonization was taken care of by Keresztury Dezső, “Útikönyvek", in: Magyar Szemle, n. 9-12 (1937), pp. 58-69, here: p. 61.

176 Undated advertisement (likely 1936), Box 36, MFM.

177 Allah Akbar. Im Banne des Islams (Berlin: Holle, 1938); Sulle orme di Maometto, 2 vols. (Milano: Treves, 1938).

178 Philip K. Hitti, History of the Arabs from the Earliest Times to the Present (New York: St. Martin's Press, 1953), p. 119. Hans-Jürgen Philipp (review author), "Bibliografija Saudovskoj Aravii (Bibliographie Saudi-Arabiens)”, in: WI, Vol. 26 (1986), pp. $243 \mathrm{ff}$.

179 Germanus claims that he spoke in Arabic (Germanus, "A félhold fakó fényében", p. 161), but from Haykal's description it is clear that what he heard was in English. Muhammad Ḥusayn Haykal, Fı̃ manzil al-wahy (Cairo: Maktabat al-Nahḍa al-Mișriyya, 1967), pp. 41 .

180 The memoirs of Győző Gerő, entitled “A sátor ajtaja mindig nyitva volt”, in: Germanus Gyula (Publication of Magyar Földrajzi Múzeum), four inserted pages, no page numbers.

181 "Emlékezéseim a PEN-Clubra", p. 8. So far, I have been unable to locate any trace of his visits to Oxford.

182 Németh, “Die Orientalistik in Ungarn 1938", p. 13. 


\section{Conclusions}

This article explained how a minor Turkologist transformed into a popular Arabist with the help of literature and religion. By following this unusual change it explored the institutions of Hungarian Orientalism in transition from an imperial to a nation-state setting. As has been the case worldwide, academic Orientalism in Hungary has been a network of educational and research institutions, mostly funded by the state budget and, as such, it has been affected by the political and economic interests of the state. The Hungarian case yet differs from the Western European establishment in that Turkish and Arabic Studies were not only learned discourses about the Other but these were to answer questions about national history and identity. Nonetheless, Orientalists in Hungary were equally constrained by politics and occasionally served political interests. During the first fifty years of Germanus' life, four ideologically different regimes followed each other. The politicians' interest in Oriental Studies was subject to their foreign policies, to theories of Hungarian origins, and to financial constraints. Institutionally, the interplay of these factors defined the funding of Orientalist professors and researchers. The pre-WWI Hungarian Orientalist academic infrastructure was designed for a large audience because of the Austro-Hungarian imperial economy, the Hungarian imperial idea, and the popular interest. After 1919, rationalizing education lead to parallel establishments under the umbrella of one university (at the Humanities and Economics Faculties), which were separated again in 1934.

Germanus' career may produce two insights. The first is that Turkish Studies and Semitic Philology in Hungary opened the door for social mobility and Jewish assimilation. The first generation of institutionalized Orientalists were either from the countryside (villages), or of Jewish origin, or often both (poor rural Jews), the best examples being Vámbéry and Goldziher. Equally poor Christian Hungarians figure amply among the 19th-century Orientalists also, from Kőrösi Csoma to Áron Szilárdy. As member of a second generation, Germanus represents an urban student from the capital with a state education, without knowing Hebrew. Taught by successful scholars at the state university, he was already equipped with a potential career-path and pattern of assimilation that may also explain his determined struggle to remain within the safe walls of academia.

This model leads to the second insight. Religion (Christianity) was crucial in career building in pre-WWII Hungary including Oriental Studies. Before being integrated into academia, Germanus converted to Calvinism. His conversion to Islam helped him to study Arabic and gather a unique, personal knowledge of contemporary Arabic literature and its creators in Egypt. Coming from an urban 
assimilated background, Germanus' credo was not loyalty to one's religion but loyalty to the state. The conversions, the travels, the literary output, and this loyalty helped him to attain fame. He successfully created a new public image. His popularity in the late 1930 s is the reason why he could restart after WWII a second, even more politicized chapter of academic career. 